\title{
Article \\ Identifying Victims of Human Trafficking at Hotspots by Focusing on People Smuggled to Europe
}

\author{
Matilde Ventrella \\ Faculty of Social Sciences, University of Wolverhampton, Wolverhampton, WV1 1AD, UK; \\ E-Mail: Matilde.Ventrella@wlv.ac.uk
}

Submitted: 31 January 2017 | Accepted: 24 March 2017 | Published: 23 June 2017

\begin{abstract}
Research has shown that smuggling of migrants is associated with human trafficking. Hence, victims of human trafficking amongst smuggled migrants should be identified by EU Member States at hotspots established by the European Commission, to overcome the migrant and refugee crisis. Identified victims should be given a visa and a programme of protection to escape their traffickers. In order to achieve these objectives, research suggests that EU law on migrant smuggling should be amended and the Temporary Protection Directive should be applied to smuggled persons when there is an indication that they may be victims of human trafficking. This approach should be adopted by the EASO in cooperation with police forces investigating smuggling and trafficking at hotspots.
\end{abstract}

\section{Keywords}

European Union; human trafficking; smuggling; Temporary Protection Directive

\section{Issue}

This article is part of the issue "Perspectives on Human Trafficking and Modern Forms of Slavery", edited by Siddharth Kara (Harvard Kennedy School, USA).

(C) 2017 by the author; licensee Cogitatio (Lisbon, Portugal). This article is licensed under a Creative Commons Attribution 4.0 International License (CC BY).

\section{Introduction}

This article addresses the issue of identification of victims of human trafficking at hotspots. For this purpose, it analyses the connections with the smuggling of migrants, because it is thought that many people smuggled into Europe from Africa and the Middle-East become victims of human trafficking either during their trip or after they reach the EU. Consequently, EU Member States should undertake interviews with migrants and investigations on human trafficking, to understand whether smuggled migrants have been accomplices of criminal networks or have simply paid for a service provided by criminal networks or, indeed, whether they have been trafficked during their journey to reach Europe or are at risk of being trafficked due to their undocumented, and hence vulnerable, status. It is the EU Member States' responsibility to undertake interviews and investigations and this article will argue that domestic law enforcement authorities should undertake interviews and investigations at hotspots with the support of the Euro- pean Asylum Support Office (EASO). Hence, the article will analyse whether hotspots are places which can provide protection to victims of human trafficking who have been previously smuggled by criminal networks from origin and transit countries. In order to achieve this objective, this section will show how people smuggling is perpetrated from Africa to Europe and the role smuggled migrants have whilst they cross different countries to reach Europe.

Smuggling of migrants is a complex crime which can take place from Sub-Saharan Africa to Europe (European Commission, DG Migration \& Home Affairs, 2015, pp. 1314). The crime is committed, by air, by land, and by sea. Smuggling by air is perpetrated by document fraud and the Nigerian Immigration Service (NIS) has reported that the price of fake documents via air from Nigeria has increased dramatically since the introduction of biometric identifiers within Nigerian passports in 2006 and improved capacity to detect fraud at the Nigerian air border (European Commission, DG Migration \& Home Affairs, 2015, p. 41). 
Smuggling of migrants by land can take place through a variety of locations in Africa and Europe. The European Commission DG Migration \& Home Affairs has conducted a study on selected routes by land; from Turkey into Bulgaria, from Ethiopia into Sudan and then onto Libya, from Pakistan to Iran and to Turkey and from Greece to Macedonia, and subsequently to Serbia and Hungary (2015, p. 38). The research revealed that the journey by land can take a long time as some of the routes smugglers use to reach Europe, have to be taken by walking through the desert and through the use of vehicles such as pickups or trucks. In the central Sahara, smuggling by land is controlled by smuggling organisations able to transport around two or three dozen passengers. The transport is organised by smugglers from different ethnic groups including Tuareg or Tebu, Hausa and Arab groups. Criminal groups are able to transport people from Sub-Saharan Africa to Libya. Journeys can take several days, weeks or months due to vehicle break down or unstable situations in many African countries. The report has shown that on many occasions migrants have been abandoned in the desert in Niger and in 2015, 48 migrants died in Niger on their way to Europe. Smuggling by sea can take place via the Mediterranean. According to the figures of the International Organisation for Migration (IOM, 2017), in between January and May 2016, 191,134 migrants reached Europe by sea compared to 5,352 who arrived in Europe by land. In 2015, 1.015,078 migrants arrived in Europe via the Mediterranean (United Nations High Commissioner for Refugees [UNHCR], 2016). The routes which are used to reach Europe via the Mediterranean are: the Eastern Mediterranean route from Turkey to Greece across the Aegean Sea followed by a journey on foot through the Western Balkans to reach their final destination in the EU; the central Mediterranean route from North Africa to Italy and the western Mediterranean route from Morocco or Algeria to Spain (Frontex, 2016). It has been estimated by Frontex that in 2015 migrants and refugees crossing the central Mediterranean route, were mainly from Eritrea, Nigeria and Somalia. In 2016, the UNHCR published new figures which showed that migrants crossing the Mediterranean were mainly from Syria, Afghanistan, Iraq, Pakistan, Iran, Nigeria, Gambia, Somalia, Cote d'Ivoire and Guinea. On the basis, of this data, it can be deducted that the inflows include refugees, asylum seekers and economic migrants.

It has been reported that most of the migrants travelling from Africa to Europe, seek and obtain the support of criminal organisations. In 2014, it was estimated that $80 \%$ of migrants were supported by criminal organisations (The Global Initiative Against Organised Crime, 2014). In 2016, a report published by Europol showed that more than $90 \%$ of migrants who leave their countries of origin irregularly are facilitated by smugglers' networks (Europol, 2016). Hence, smuggling networks are becoming stronger and are able to control the irregular routes. Despite these statistics, there is not a clear picture of the scale of the organised criminal groups that smuggle migrants. According to the report published by the DG Migration \& Home Affairs, smuggling of migrants is a very well organised crime where criminal groups are hierarchically structured and connected with other criminal groups such as the Italian Mafia (2015, pp. 47-51, 53-54). It has also been reported that criminal groups liaise with corrupted police officers in transit countries (p. 49). However, the Migration Envoy, Europe Directorate, and FCO in the UK reported that currently, no large-scale organised criminal groups are perpetrating the smuggling of migrants (p. 49). Clearly, there is inconsistency between this information which demonstrates that the crime of smuggling of migrants is not yet wellknown. The lack of knowledge can make it difficult to understand the links between smuggling and trafficking and can leave many victims of trafficking unidentified.

\section{Connections between Smuggling and Human Trafficking}

Understanding connections between smuggling and trafficking can reduce the latter crime by reducing the chances of people who are smuggled becoming victims of trafficking during their journeys and once they reach Europe. It has been reported that there are three ways by which a smuggled migrant can become a victim of trafficking (Triandafyllidou \& Maroukis, 2012, p. 191). One way is due to the fact that when the migrant has reached their final destination the tie with the smugglers does not end at the end of their trip. Even after the end of their journey, migrants can become victims of trafficking as they may be obliged to repay the price of their trip. Nevertheless, this practice does not seem to be in use anymore on the southern Mediterranean route, as migrants are expected to pay the price of their journey in advance before they travel from Egypt and Libya (European Commission, DG Migration \& Home Affairs, 2015 , p. 46). Another way by which smuggling can become trafficking is when the migrant is still travelling to reach his or her final destination and is trafficked either for the purpose of sexual exploitation or forced labour or drug smuggling (Triandafyllidou \& Maroukis, 2012, p. 192). There are also reports which show that women become victims of torture and rape whilst travelling from the Sub-Saharan Africa (European Commission, DG Migration \& Home Affairs, 2015, p. 20). These reports have been confirmed by recent investigations conducted by Italian public prosecutors in Palermo (Italy) in the Glauco case I (Fedotov, 2016), who successfully detected a criminal network which smuggled migrants from Libya, Eritrea, Ethiopia, Sudan and Israel to Sicily (Procura della Repubblica presso il Tribunale di Palermo, 2014, p. 16). Subsequently, the same organisation smuggled migrants to Northern Italy and eventually to Sweden, Germany, Norway, the Netherlands, France, Austria, Australia and Canada (p. 2). During the investigations, public prosecutors found that migrants had been kidnapped, tortured and raped (pp. 41-61). In addition, kidnapped migrants 
had been kept in detention in Libya until their families, contacted by the organisations, paid the ransom for their release. One of the migrants from Eritrea witnessed that the criminal network was able to contact his mother in Eritrea and ask for the payment of US\$3300 in exchange for his release (p. 43). In prison, migrants have been forced to witness torture of other migrants and they have been forced to stand on their feet while they were beaten and tortured by electric discharge. Public prosecutors stated that these cases fall within the scope of human trafficking as the consent, which was initially given, had lost its validity since it was no longer free, unconditional or reversible (p. 13).

The final way in which smuggling can become trafficking is enslavement which arises out of employment opportunities during the migrant's trip (Triandafyllidou \& Maroukis, 2012, p. 192). Usually, migrants start to work in sweatshops or in the construction sector and soon realise they are trapped. In other cases, migrants whilst en route, become part of the smuggling business to be able to pay part of their journey. These cases should be clearly investigated and distinguished from cases of smuggling where these violations of human rights do not occur.

Research conducted from 1990 to 2015, in the Italian region of Apulia, has revealed that the smuggling of migrants is not always connected to trafficking and that it is not always centralised and highly organised criminal networks which smuggle people (Achilli, 2015, p. 4). Smuggling groups analysed by this particular research, are characterised by heterogeneity and, in the Eastern Mediterranean, they mainly consist of family-based businesses (p. 5). It has also been reported that for many irregular migrants, smugglers are the only way to escape from poverty and other dangerous situations (p. 6). In other terms, smugglers may be providing a service without exploiting migrants and asylum seekers who, conversely, may work for smugglers as recruiters, intermediaries and in other positions (p. 7). Hence, investigating whether migrants have been victimised by smugglers and traffickers is very important, in order to understand links between smuggling and trafficking and to be able to address these criminal activities. Certainly, as public prosecutors in Palermo highlighted, smuggling and trafficking can be defeated by EU policy on legal migration as this policy could reduce demand by people who otherwise would not be able to leave their countries of origin when they are in a situation of danger or poverty (p. 10). In the meantime, migrants who risk becoming victims of trafficking should be protected, by adopting a policy which is addressed specifically to them.

The European Commission has published the European Agenda for Migration and has identified as a priority the fight against migrant smuggling and trafficking of human beings (European Commission, 2015b, p. 9). For this purpose, it has highlighted how important is to address the root causes of irregular migration and to cooperate with third countries to fight against criminal networks (pp. 7-8). It has also emphasised that EU agen- cies can support Member States to identify smugglers, to investigate and prosecute them, as well as to freeze and confiscate their assets. However, the Agenda seems to concentrate on security rather than on the protection of victims of trafficking. Conversely, identifying victims and obtaining their support in investigations, can make the difference in the fight against these crimes because the victims can act as witnesses against smugglers who eventually become traffickers, as police officers and public prosecutors in Italy have clearly shown (Ventrella, 2010, pp. 196-201, 208-213). The Agenda on Migration has established hotspots to support frontline Member States to manage migrants, asylum seekers and refugees' arrivals, and to address smuggling and trafficking (European Commission, 2015b, pp. 6-18). The next section will focus on EU policy to overcome the migrant and refugee crisis, and on hotspots in order to evaluate whether EU policy including external relations to deal with the migrant and refugee crisis, permit the identification of victims of human trafficking within those who have been smuggled.

\section{The Hotspots Approach}

\subsection{Introduction}

The migrant and refugee crisis in the EU is a multifaceted problem which should be tackled by multifaceted actions oriented not only to asylum seekers and refugees, but also to economic irregular migrants because, as the UNHCR reported, in Europe there are mixed migration flows, made up of refugees and economic migrants who use the same routes and rely on the same smugglers (2007). However, identifying exactly how many people are refugees and how many are economic migrants looking for a better life in Europe, requires information about the cause of migration which is lacking (Fargues \& Bonfanti, 2014). Statistics on migrants at sea stop when they land and no one really knows what they do once they land and what their fate is. Hence, it is important to focus on the root causes of migration to identify the categories of migrants who leave their countries of origin, in order to implement adequate global actions to prevent them from leaving in poor conditions and risking their lives. The need for global action is confirmed by the High Representative Vice President (HRVP) Federica Mogherini, who stated that the EU is dealing with a migration and refugee crisis that should be tackled by global action because 'It is a regional crisis: it's not only a European crisis, it is a regional crisis... and a global crisis, too...' (2015). The HRVP asserted that in order to address this emergency, it is essential to strengthen cooperation between Member States on the basis of 'five different elements'. The first element should focus on the protection of asylum seekers as they are entitled to refugee status. The second element should consist of managing EU borders by fully respecting human rights. The third element should be to fight against smugglers and traffick- 
ers by operating in the high sea against smugglers at sea. Actions against smugglers and traffickers should also be taken on the mainland when the crime affects the Western Balkan route. The fourth element should address the EU external action and strengthen the partnership with third countries, especially countries of origin and transit to create economic development and job opportunities. Finally, the HRVP stated that the crisis could be overcome by addressing the root causes of migration. Mogherini asserted that this crisis can be overcome by cooperating with transit and origin countries not only on readmission and return agreements, but also on the economic developments and opportunities in these countries. Through this proposal, the HRVP confirmed that the problem involves not only asylum seekers and refugees, but also economic irregular migrants and this is why EU external actions should be promoted to address and tackle the root causes of economic irregular migration by economic developments. Improving economic conditions of countries of origin would give many people the option not to leave their countries unlawfully and to avoid having to trust criminal organisations which eventually may exploit them.

However, in September 2015, the Council established two provisional Decisions (Council of the European Union, 2015b, 2015c), based on Article 78(3) TFEU, which states that provisional measures can be adopted by the Council when one or more Member States are confronted by emergencies 'characterised by a sudden inflow of nationals of third countries'. The countries affected by such emergencies were Greece and Italy (para. 9). According to these decisions, only asylum seekers with $75 \%$ or more of the asylum recognition rate will be relocated (para. 20). At the moment, relocated people have mostly been nationals from Syria, Eritrea, Iraq, Central African Republic, Yemen, Bahrain and Swaziland (European Migration Network, 2015, p. 2). In addition, the European Commission reported that Member States have offered relocation to only 2000 people and only twelve Member States have relocated them, whilst five Member States have not relocated any individuals, although in 2017 other migrants have been relocated and the situation has improved compared to 2016. (European Commission, 2016a, p. 11, 2017). Moreover, what of the people who do not score $75 \%$ of the asylum recognition rate? What is their fate? They risk being returned to their countries of origin even if they may face violations of their human rights (Webber, 2015). In addition, what about investigations of smuggling and trafficking? There may be many cases of victims of trafficking from other African countries, as shown in the previous section, who risk remaining without protection and being vulnerable to becoming victims of trafficking again. No EU measures address this problem. The EU continues to focus on security and this is confirmed by the fact that it has adopted a military operation called EUNAVFOR MED to combat the smuggling of migrants by sea, which has the power to arrest smugglers and dispose of vessels but does not have jurisdiction over investigations (Council of the European Union, 2015a). The EUNAVFOR MED has been identified as 'a police mission with military means' (Den Heijer, Rijpma, \& Spijkerboer, 2016), focused on security rather than border management. The limited scope of EUNAVFOR MED cannot support Member States in identifying victims of trafficking amongst smuggled migrants. In addition, Human Rights Watch has reported that EUNAVFOR MED, by diverting vessels in the sea, may contribute to violation of human rights, refoulment and may push migrants and smugglers to engage in even more dangerous journeys (Human Rights Watch, 2015). Hence, EUNAVFOR MED is another measure adopted to secure EU borders as opposed to protecting vulnerable migrants from trafficking. The EU has also established hotspots to identify asylum seekers and distinguish them from other categories of migrants. The former should be provided protection whilst the latter should be returned to their countries of origin or residence. The next sections analyses hotspots and argues that these are not places where victims of human trafficking are identified and thus, they should be reformed.

\subsection{The Establishment of Hotspots}

The EU adopted the hotspots approach in 2015, to ensure that the EASO, Frontex and Europol work with frontline Member States to identify, register and fingerprint migrants (European Commission, 2015b, p. 6). Individuals who claim asylum will undergo the asylum procedures and will be assisted by the EASO, the others will be assisted by Frontex which will support Member States to return all irregular migrants. In addition, the Commission stated that 'Europol and Eurojust will assist the host Member State with investigations to dismantle the smuggling and trafficking networks'. The Commission highlighted that hotspots shall 'ensure screening, identification and fingerprinting' (European Commission, 2016a, p. 11) of irregular migrants reaching the EU from its external border. Fingerprinted and registered migrants will be channelled either through 'the national asylum system', 'the European relocation system' or 'the return system'. The system will be automatic and aimed at returning as many irregular migrants as possible in an emergency situation (European Commission, 2016a p. 8; Ippolito, 2016). Hotspots have been established in Greece and Italy (European Commission, 2015c, 2015d). In Greece, 5 hotspot areas have been identified; Lesvos, Leros, Kos, Chios and Samos, although only Lesvos is carrying out the identification, fingerprinting and registration of migrants and asylum seekers (European Commission, 2015c, p. 5). In Italy, 6 hotspot areas have been identified; Lampedusa, PozzaIlo, Porto Empedocle/Villa Sikania, Trapani, Augusta and Taranto. The European Commission has reported that hotspots are fully operating in Greece and in Italy, apart from Kos in Greece and Porto Empedocle and Augusta in Italy (European Commission, 2016b). 
The different agencies have different roles. Frontex provides operational cooperation at the request of Member States (Statewatch, 2015, p. 1). Actually, Frontex's scope has been enhanced by Regulation 2016/1624 which established the European Border and Coastguard Agency (European Parliament \& Council of the European Union, 2016b). The new Regulation states that the European Border and Coastguard Agency has to ensure the management of border crossings at the EU external border, including:

addressing migratory challenges and potential future threats at those borders, thereby contributing to addressing serious crime with a cross-border dimension, to ensure a high level of internal security within the Union in full respect for fundamental rights, while safeguarding the free movement of persons within it. (Article 1)

At hotspots, Frontex supports Member States in registering and screening irregular migrants, although the main responsibility for fingerprinting and EURODAC registration remains Member States' responsibility (DirectorateGeneral for Internal Policies, 2016, p. 27). Frontex also supports Member States in returning irregular migrants not entitled to asylum and in dealing with unclear situations. Frontex gathers information from migrants about routes and the modus operandi of criminal networks with the information being subsequently shared with Europol (pp. 27-28). Europol supports Member States in investigations concerning the smuggling of migrants by sea and related crimes (Statewatch, 2015, p. 2).

EASO supports Member States to process and facilitate the analysis of asylum applications through joint processing with the objective of channelling asylum seekers into the appropriate asylum procedures (DirectorateGeneral for Internal Policies, p. 28; Statewatch, 2015, p. 2). The main task of EASO is to assist Member States in relocating asylum seekers who are entitled to refugee status.

Eurojust strengthens cooperation and coordination between Member States in the investigation and prosecution of those carrying out cross-border crimes (Statewatch, 2015, p. 1). These agencies operate at hotspots where there is a high level of migration pressure and where there are mixed migration flows generally linked to the smuggling of migrants. At hotspots, Member States submit a request of support to the European Commission and to the relevant agencies. The work at hotspots is coordinated by an EU Regional Task Force (EURTF) where EASO, Europol and Frontex deploy their staff. Eurojust may also consider deploying their staff to the EURTF (Statewatch, 2015, p. 3).

Hotspots have been criticised because the relocation of people in need of international protection depends on the nationality of the asylum seeker. (DirectorateGeneral for Internal Policies, 2016, p. 30). The process is very quick as one of the aims of hotspots is to identify, register and process migrants quickly in order to de- termine whether migrants can be entitled to asylum or they have to be returned to their countries of origin or residence. Screening at hotspots could result in the separation of 'good' refugees from 'bad' economic migrants and leave many people in an unsafe situation without giving appropriate consideration to their claims (Webber, 2015).

The EU Agency for Fundamental Rights has criticised hotspots as there is the risk of a surge in collective expulsion $(2015$, p. 12). Certainly, hotspots have improved the registration of arrivals in Greece and the European Commission has pointed out that hotspots in Greece have improved the fingerprinting rate from $8 \%$ to $78 \%$ and $100 \%$ by March 2016 (Directorate-General for Internal Policies, 2016, p. 36). However, it has been reported that the focus of hotspots in Greece 'has been on identification, registration and border control (p. 37). The same can be noted of hotspots in Italy where the majority of staff deployed to hotspots are from Frontex, which is in line with the main aim of hotspots which were initially created to identify and register migrants (p. 38). EASO presence in Italian hotspots is very limited and Europol is completely absent. People coming from non-qualifying countries such as Gambia, Nigeria and Senegal, are treated as non-refugees and there is no mechanism in place to permit these migrants to apply for international protection even if they do not come from qualifying countries (p. 40). Caritas Europa has reported:

People coming from Sub-Saharan African countries that are considered safe are with deportation orders as soon as they arrive on the Italian territory. They are not informed on asylum possibilities and the authorities present in the hotspot..., do not give them the opportunity to claim asylum.' (Caritas Europa, 2016)

Migrants should always be given the opportunity to apply for international protection even if they do not qualify for relocation (Directorate-General for Internal Policies, 2016, p. 44). Their application should be assessed impartially and on a case-by-case basis with migrants only being returned when it has been assessed that their return will not be in breach of the principle of non-refoulement and of the proportionality check. It is emphasised that EASO should be given a new mandate in order to facilitate the adequate functioning of the Common European Asylum System (CEAS). In this article, it is thought that their mandate should include the identification of victims of human trafficking amongst smuggled migrants as these people are in need of international protection even if they do not come from countries eligible for relocation.

\subsection{Identification of Trafficking Victims at Hotspots}

Hotspots do not address human trafficking and smuggling by identifying victims and providing support, although the Commission stressed how important is to identify victims of human trafficking at hotspots (Eu- 
ropean Commission, 2015b, p. 6). The Commission stressed that smuggling and trafficking should be fought by cooperation with transit countries 'to prevent and detect smuggling activities as early as possible' (European Commission, 2015a, p. 18) as well as by maximising cooperation with Europol and Eurojust in detecting trafficking. No attention has been given to how victims of trafficking should be identified amongst smuggled migrants. The EU Select Committee of the House of Lords stated that 'It is very disappointing that no meaningful proposals have been made to address assistance to vulnerable smuggled migrants' (House of Lords European Union Committee, 2016, p. 31).

There is evidence showing that criminal networks have exploited the migration crisis to target vulnerable migrants with over $60 \%$ of unaccompanied children missing and being at serious risk of becoming victims of human trafficking (European Commission, 2016a, p. 16). Furthermore, Europol has indicated that many criminal networks smuggle refugees with the intention to exploit them in the sex trade or to use them as forced labour. Many migrants left at the hotspots could be recruited by traffickers for such purposes and transferred to other Member States. In the UK, for example, there is a high rate of human trafficking for labour exploitation which prevails over trafficking for sexual exploitation (AntiTrafficking Monitoring Group, 2013, p. 18; Cepeda \& Sánchez, 2014). Research has revealed that forced labour is linked to trafficking and that many undocumented migrants who entered the UK via smuggling or trafficking routes, have become victims of trafficking for the purpose of sexual exploitation and forced labour (Clark, 2013, p. 62; Dwyer, Lewis, Scullion, \& Waite, 2011, p. 16). Hence, it is important to understand how smuggled migrants become victims of trafficking and transferred to the UK for such purposes. In order to achieve this objective, investigations should be initiated at hotspots. This is because the Commission stressed that the first step to protect victims and prevent trafficking is to identify actual or potential victims at the hotspots (European Commission, 2015b, p. 6). Actual or potential victims should be 'made aware of their rights and that the necessary cooperation should take place with the police and judicial authorities in order to ensure that traffickers are identified and prosecuted.' This is not being put in place at hotspots and migrants have reported that victims of torture and other forms of violence hosted in Greece do not receive any information either about their situation, their legal options or about their rights (Pro Asyl, 2016, p. 29). It seems to be that because migrants initially gave their consent to be recruited by smugglers, that this justifies the domestic authority's neglect of them and the lack of investigation of the possible links between smuggling and trafficking.

Investigations on the smuggling of migrants undertaken in Palermo, for example, have revealed that public opinion and some stakeholders working in the field of smuggling and trafficking, mistakenly emphasise that the consent, initially given by migrants, should be the reason to blame victims of human trafficking for having ended up being exploited (Procura della Repubblica presso il Tribunale di Palermo, 2014, pp. 12-13). The public opinion and some stakeholders use to distinguish between culpable consent and innocent consent by shifting the burden of proof to the victim and by considering an innocent victim a being only those who can demonstrate that they were forced into being trafficked for the purpose of sexual exploitation, forced labour or other forms of trafficking. The victim is culpable when he or she has chosen to emigrate irregularly (p. 13). In other words, the decision to leave their country irregularly is the reason why the victim is not innocent but culpable. Furthermore, public opinion and some stakeholders do not consider the fact that exploiters may have misled migrants to obtain the consent to be smuggled, prior to the smugglers becoming traffickers as a result of the exploitation, torture, rape and use of other forms of coercion against vulnerable migrants (p. 12). Hence, public prosecutors emphasised that it is important to investigate all the different phases of smuggling, in order to understand whether this criminal activity is connected to a possible human trafficking.

How should victims be identified at hotspots? How should victims be separated from smuggled people who have not become victims of human trafficking? It is thought that the identification should be undertaken by approaching and interviewing smuggled migrants. Hotspots should be improved, in order to protect vulnerable smuggled migrants. Early identification systems should be launched to give assistance to smuggled migrants who have been trafficked or are at risk of being trafficked due to their particular circumstances which should be evaluated on a case-by-case basis.

The Group of Experts on Action against Trafficking in Human Beings (GRETA) established by the Council of Europe to monitor how State Parties of the European Convention on human trafficking apply it (GRETA, 2014) emphasised that, in order to identify victims amongst irregular migrants, a priority should be to adequately train border police officers, asylum officials, members of staff of reception centres for asylum seekers and irregular migrants, as well as judicial bodies in charge of issuing expulsion (GRETA, 2015, p. 31). GRETA reported that in some Member States such training does not take place (GRETA, 2013, p. 31). The Commission highlighted that this is the reason why the prosecution and conviction of human trafficking 'remains worryingly low' (European Commission, 2016c, p. 10). The Commission also emphasised that whilst it is important for Member States to investigate and prosecute traffickers, they need to develop regular training for investigators, prosecutors and judges (p. 11). There is too much burden on victims and on their testimonies during criminal investigations and the Commission has reported that often victims are refused assistance by domestic police (pp. 10-11). Victims are often misidentified as criminals and prosecuted rather than protected (European Commission, 2015b, p. 6). 


\subsection{The Legal Obligation to Protect Victims of Human Trafficking}

Member States have a legal obligation to protect victims of human trafficking. According to the Council of Europe Convention on Action against Trafficking in Human Beings (2005, Article 10(1)), victims shall be identified by competent authorities of State Parties and protected. The Trafficking Directive (European Parliament \& Council of the European Union, 2011) requires that Member States implement early identification mechanisms of assistance, in order to protect victims of human trafficking (Article 11(4)). Member States shall ensure that victims receive legal representation, legal counsel and access to specific schemes for the protection of witnesses, based on individual risk assessments, in accordance with domestic law and procedures. Victims shall be protected against victimisation which may occur when they are interviewed and when they give evidence in court (Article 12 (2,3 and 4)). The European Court of Human Rights (ECHR) has expressly recognised that State Parties have the positive obligation to protect victims of trafficking which, is considered a form of slavery and prohibited by Article 4 of the Convention for the Protection of Human Rights and Fundamental Freedoms (Council of Europe, 1963) as well as to prosecute the perpetrators (Rantsev v. Cyprus and Russia, 2010, para. 282-283; Siliadin v. France, 2005, para 112). The ECHR has been very strict on this point and has sanctioned Greece because they didn't protect a victim of human trafficking as they didn't undertake investigations into the trafficking and didn't prosecute criminals in a reasonable time (L.E. v. Greece, 2016). However, how should people be protected if they haven't made any claim? Many smuggled migrants, apparently not entitled to asylum, may be victims of human trafficking. Research has shown that victims of human trafficking usually do not make claims, unless police and non-governmental organisations adopt specific programmes of protection for them (Ventrella, 2010, pp. 208-213). It has been reported that victims of trafficking may not make claims because they may suffer from post-traumatic stress which can cause loss of memory and thus, they may forget the names of their traffickers (Triandafyllidou \& Maroukis, 2012, pp. 183-186). Another reason they may not claim is because they fear the juju ritual, common amongst victims from West Africa and Sub-Saharan Africa and which prohibits victims from revealing what happened during their journey. It must be added that victims of human trafficking for sexual exploitation, for example, may not make any claims because they feel guilty for having been exploited (pp. 183-186). Victims may also not make claims because they fear retaliation (Ventrella, 2010, pp. 208-213). Police officers and members of humanitarian organisations interviewed in Rimini and Siracusa (Italy) have explained that victims they approached, refused for a long time to make claims as they feared retaliation (pp. 197-199, 208-212). When victims decide to testify, they and their families in their countries of ori- gin, have received threats and as a result, it has been reported by police, that members of their families in their countries of origin have been murdered, a fact which demonstrates the strength of the connections between criminal networks in different countries. Hence, it is important that Member States take their responsibility to identify victims beyond the fact that they may not claim their status and at a very early stage, immediately after migrants reach the hotspots, by avoiding the automatic return of migrants who do not make claims but who may be victims of human trafficking. Member States have to take their responsibility on the basis of the law examined in this section and on the basis of Article 4 Protocol 4 ECHR which prohibits collective expulsion and which can permit the early identification of victims. The ECHR has obliged Member States to examine the situation of all migrants who land in Europe no matter whether or not they are migrants or 'genuine' asylum seekers (Becker $v$. Denmark, 1975; Conka v. Belgium, 2002; Hirsi Jamaa and Others v. Italy, 2012; Khlaifia and others v. Italy, 2015). On the basis of the ECHR case-law, Member States shall disembark all migrants and hear them singularly. In other words, when migrants have been rescued, they have the right to be heard on a case-by-case basis, even when they are not entitled to asylum. Hence, when migrants approach the hotspots, they should be heard by EASO in cooperation with trained personnel and domestic police which should take the opportunity to identify victims of trafficking amongst smuggled migrants. The Commission clearly stated that the hotspots approach requires that the EASO, Frontex and Europol work together to identify asylum seekers and irregular migrants (European Commission, 2015b, p. 6). However, in terms of smuggling and trafficking, the Commission only states that 'Europol and Eurojust will assist the host Member State with investigations to dismantle the smuggling and trafficking networks'. No parts of the EU Agenda on Migration focuses on how EASO can support the identification of trafficking victims amongst smuggled people. Conversely, the EASO's mandate should be enhanced to permit their staff to identify victims of human trafficking amongst smuggled migrants and to provide them with international protection. This is why it is very important to give EASO a stronger mandate as emphasised by the DirectorateGeneral for Internal Policy Department.

Actually, the identification of trafficked people in between smuggled migrants is made difficult, not only by the hotspot approach but also by the EU Return Directive (European Parliament \& Council of the European Union, 2008) and case-law of the Court of Justice of the European Union (CJEU) on this Directive.

\section{Incompatibility in between the EU Return Directive and the Right of Victims of Human Trafficking to Be Identified}

Migrants who have been smuggled and who are not asylum seekers, refugees or victims of human trafficking, 
have to be returned to their countries of origin or permanent residence. The return of irregular migrants is established by the EU Return Directive (European Parliament \& Council of the European Union, 2008). Prior to their return, migrants, have the right to be heard, otherwise Member States competent authorities would be in breach of Article 4 Protocol 4 ECHR and subsequent ECHR case-law.

The CJEU has ruled on the right of migrants to be heard prior returning to their countries of nationality or of residence (Kamino International Logistics, 2014, para. 29; Mukarubega, 2014, para. 43). Settled case-law has established that the respect of the right of defence and of the right to be heard can be restricted if this is in compliance with the general interests pursued by an adopted law measure, unless the objectives of the measure are 'a disproportionate and intolerable interference which infringes upon the very substance of the rights guaranteed' (Alassini and Others, 2010, para. 63; Boudjlida, 2014, para. 43; G. and R., 2013, para. 33; Texdata Software, 2013, para. 84). The objective of the Return Directive is 'the effective return of illegal-staying third-country nationals to their countries of origin' (Boudjlida, 2014, para. 45). For this purpose, the return decision must be adopted as soon as domestic authorities determine that the stay is illegal (para. 46; Achughbabian, para. 31).

The return decision must be taken in compliance with Article 5 of the Return Directive and thus, 'the best interest of the child', 'family life' 'the state of health of the third-country national concerned'; 'and the respect of non-refoulement have to be respected and, for this purpose, persons concerned must be heard (para. 49). Domestic competent authorities shall provide all information relating to their particular situation in order to justify why a return decision cannot be issued in their case (para. 50). Victims of trafficking can be protected under Article 5 if they make claims and if, after investigations based on the Trafficking Directive and the Council of Europe Convention against human trafficking, it is concluded that their return would be a violation of the principle of non-refoulement. In all cases not contemplating the exceptions of Article 5, the competent authorities do not have the legal obligation to disclose evidence in advance prior to interviewing to the illegal stayers or to grant them a reflection period (paras. 53-59). The right to be heard prior the adoption of a return decision, shall permit the domestic competent authority, to undertake an investigation only on the matter concerning return of the illegal stayer and to give a decision where reasons are adequately stated so that the person concerned will be able to bring legal action against the decision (para. 59). The CJEU neglects victims of trafficking who do not make claims, as it does not permit smuggled migrants who might have become victims of trafficking during their journey, to be given a reflection period. The CJEU is in compliance with Article 5 as this provision does not recall legal instruments on human trafficking and on people smuggling. Early identification mech- anisms established by law on human trafficking, are not recalled by Article 5 . The problem is that the Return Directive leaves too much discretion to Member States in identifying the categories of migrants who fall within the scope of this Article. Such discretion is allowed because the EU Return Directive is focused only on returning migrants and in order to achieve this purpose, the Directive risks contributing to the neglect of trafficked people who do not make claims. The return of irregular stayers should be adopted only when police authorities and the EASO at hotspots are satisfied that there are no victims of trafficking amongst the illegal stayers to be returned. Unfortunately, a new Draft Regulation aims to increase return of irregular migrants and the adoption of this legal measure may be even more detrimental to the victims of human trafficking (European Parliament \& Council of the European Union, 2016a). Conversely, at hotspots, the Temporary Protection Directive (Council of the European Union, 2001) should be applied by national authorities and the EASO working within the hotspots.

\section{The Temporary Protection Directive and Its Application at Hotspots}

The Temporary Protection Directive has the objective 'to establish minimum standards for giving temporary protection in the event of a mass influx of displaced persons from third countries' (Article 1). As Ineli-Ciger pointed out, the Temporary Directive has an 'added value' (2016, p. 20) which is 'its flexible eligibility criteria and its broad personal scope' (p. 20). It can be noted that because of its flexibility, it does not require that irregular migrants claim to be victims of human trafficking. By comparing the Temporary Protection Directive with the recast Directive on the reception of applicants for international protection (European Parliament \& Council of the European Union, 2013), for example, it can be noted that whilst Article $21(1)$ of the recast Directive states that victims of human trafficking can be considered vulnerable persons, after they have made an application for international protection, the Temporary Protection Directive does not require that irregular migrants make an application and thus, a claim. The Temporary Protection Directive can be applied when there is a surge in the number of arrivals. Peers pointed that 'the grounds in the temporary protection Directive are clearly non-exhaustive' (Peers, 2015, p. 573). This is because Article 2(c) states that displaced persons are third country nationals or stateless persons who may fall within the scope of the Geneva Convention 'or other international or national instruments giving international protection'. Peers stressed that, on the basis of this provision, temporary protection could be afforded to persons fleeing environmental disasters. On the basis of this interpretation, it can be asserted that the Temporary Directive Protection can also be applied to smuggled migrants when there are circumstantial indications that they have been victims of human trafficking who have not made claims. The reason for this interpretation is be- 
cause victims of human trafficking are in need of international protection. This approach can be extended to smuggled migrants as they may be entitled to a visa on the basis of the Residence Permit Directive (Council of the European Union, 2004). Article 3(2) states that 'Member States may apply this Directive to the third-country nationals who have been the subject of an action to facilitate illegal immigration' (Council of the European Union, 2004). Certainly, the issue of a resident permit to people who have been smuggled is optional and not compulsory as it is in the case of victims of trafficking. However, if applied in connection with the Temporary Protection Directive, it can become compulsory as it could be the only way to identify victims of trafficking amongst smuggled people. Indeed, if victims of trafficking do not make any claims, by granting a visa to smuggled people who may have been victims of trafficking, the EASO in cooperation with domestic police, can have the opportunity to identify victims of trafficking at the hotspots. This is because smuggled migrants will not be automatically returned to their countries of origin as requested by the EU Return Directive. Hence, even if victims of trafficking do not make any claims, it will be possible to identify them. Without applying the Temporary Protection Directive, many victims of trafficking may never be protected. This is because Article 4(1) of the Directive states that the duration of temporary protection shall be one year'. It also states that the duration 'may be extended automatically by six monthly periods for a maximum of one year' and, according to Article 4(2), for another year. This means that the EASO and police forces may have up to three years to identify victims of trafficking amongst smuggled people. This is exactly what they need as previous research conducted in Rimini has shown that police forces, in cooperation with local humanitarian organisations, took many years to completely defeat the crime of trafficking in that city because the identification of victims was very difficult. Victims were reluctant to claim and report traffickers due to the fear of retaliation (Ventrella, 2007, pp. 80-85).

Can a similar approach be a pull factor? Ineli-Ciger (2015) argues that the Directive on temporary protection has not been activated because Member States fear that it could create a pull factor because many smuggled people may make false claims to obtain a visa in Europe. It is thought that this is very unlikely as smuggled people who have not been victims of human trafficking clearly state this fact. They consider smugglers their only hope to reach Europe and they accept to pay the price for their journey as they think the activity of smugglers is a service that should be paid for (Achilli, 2015). The problem exists when there are people who do not speak out and do not make any claims. The Commission has reported that victims are hesitant to cooperate with investigative authorities 'and this can still jeopardise their access to assistance and support' (European Commission, 2016d, p. 43). In past research undertaken in Siracusa (Italy), police officers and public prosecutors stated that people who have been victims of human trafficking do not make claims. However, if there are people who make false claims, it is a task and ability of police and public prosecutors to understand the person is not a victim but just a false claimant and these principles apply for all crimes (Ventrella, 2007). Hence, a different approach at hotspots is possible.

\section{Conclusions}

This article has dealt with connections between the smuggling of migrants and human trafficking. The article has stressed that not all smuggled people are victims of trafficking. Migrants who take the decision to leave their countries of origin, look for smugglers and are aware they are providing a valuable service for them which has to be paid for. However, there are categories of migrants who become victims of human trafficking during their journey from Africa to Europe. Despite this, they have the right to be heard by national authorities of Member States, as Member States have to comply with the prohibition of collective expulsion, EU law and CJEU case-law do not facilitate the identification of victims of human trafficking amongst smuggled people. Now that hotspots have been established, it is time to adopt legislation to facilitate the identification of victims of human trafficking, otherwise, the crime will not be defeated and vulnerable migrants will continue to become victims. This approach should be adopted at hotspots created in Italy and Greece and new hotspots should be created in Turkey where victims of human trafficking should be identified amongst smuggled migrants.

Law on people smuggling should insert provisions which state that Member States shall take the responsibility to identify victims of human trafficking within hotspots and in cooperation with the EASO whose mandate should be increased to permit the identification of victims of human trafficking by identifying them at hotspots. In addition, EASO and domestic police should evaluate whether the Temporary Protection Directive should be applied when there is circumstantial indication that people who do not make claims have become victims of human trafficking during their journeys.

\section{Acknowledgements}

I thank the three anonymous referees for the insightful comments and advice they gave me in an earlier draft of this article.

\section{Conflict of Interests}

The author declares no conflict of interests.

\section{References}

Achilli, L. (2015). The smuggler: hero or felon? Retrieved from http://cadmus.eui.eu/bitstream/handle/1814/ 36296/MPC_2015_10_PB.pdf?sequence $=1$ 
Achughbabian 2011 Case C-329/11 EU:C:2011:807.

Agency for Fundamental Rights. (2015). FRA Opinion concerning an EU common list of safe countries of origin. Retrieved from http://fra.europa.eu/en/opinion/ 2016/fra-opinion-concerning-eu-common-list-safecountries-origin

Alassini and Others 2010 Case C-317/08 to C-320/08 EU:C:2010:146.

Anti-Trafficking Monitoring Group. (2013). In the dock. Examining the UK's criminal justice response to trafficking. Anti-Trafficking Monitoring Group.

Becker v. Denmark 1975 Application no. 7011/75.

Boudjlida 2014 Case C-249/13 EU:C:2014:2431.

Caritas Europa. (2016). The hotspot approach. Retrieved from http://www.caritas.eu/news/the-hotspot-ap proach

Cepeda, A. I. P., \& Sánchez, C. D. B. (2014). Trafficking in human beings: a comparative study of the international legal documents. Europa Law Publishing.

Clark, N. (2013). Detecting and tackling forced labour in Europe. Retrieved from https://www.jrf.org.uk/sites/ default/files/jrf/migrated/files/forced-labour-europe -full.pdf

Conka v. Belgium 2002 ECHR 20021.

Council of Europe. (1963). Protocol No. 4 to the Convention for the Protection of Human Rights and Fundamental Freedoms, securing certain rights and freedoms other than those already included in the Convention and in the first Protocol thereto. Retrieved from http://conventions.coe.int/Treaty/en/ Treaties/Html/046.htm

Council of Europe. (2005). Council of Europe convention on action against trafficking in human beings. Retrieved from https://rm.coe.int/168008371d

Council of the European Union. (2001). Council Directive 2001/55/EC of 20 July 2001 on minimum standards for giving temporary protection in the event of a mass influx of displaced persons and on measures promoting a balance of efforts between Member States in receiving such persons and bearing the consequences thereof. OJ L 212/12, 7/8/2001.

Council of the European Union. (2004). Council Directive 2004/81/EC of 29 April 2004 on the residence permit issued to third-country nationals who are victims of trafficking in human beings or who have been the subject of an action to facilitate illegal immigration, who cooperate with the competent authorities. OJ L 261 p. $19,6 / 8 / 2004$.

Council of the European Union. (2015a). Council decision (CFSP) 2015/778 of 18 May 2015 on a European Union military operation in the Southern Central Mediterranean (EUNAVFOR MED). OJ L 122/31, 19/5/2015.

Council of the European Union. (2015b). Council decision (EU) 2015/1523 of 14 September 2015 establishing provisional measures in the area of international protection for the benefit of Italy and of Greece. OJ L 239, $15 / 9 / 2015$.
Council of the European Union. (2015c). Council Decision (EU) 2015/1601 of 22 September 2015 establishing provisional measures in the area of international protection for the benefit of Italy and Greece. OJ L239/146, 15/9/2015.

Den Heijer, M., Rijpma, J., \& Spijkerboer, T. (2016). Coercion, prohibition and great expectations. The continuing failure of the Common European Asylum System. Retrieved from http://www.statewatch.org/ news/2016/sep/ceas-den-heijer-rijpma-spijkerboerCMLR-def.pdf

Directorate-General for Internal Policies. (2016). On the frontline: The hotspot approach to managing migration. Retrieved from http://www.europarl.europa. eu/RegData/etudes/STUD/2016/556942/IPOL_STU (2016)556942_EN.pdf

Dwyer, P. Lewis, H., Scullion, L. and Waite, L. (2011) Forced labour and UK immigration policy: Status matters? Retrieved from https://www.jrf.org.uk/file/ 41487/download?token=DsgZ8vrL

European Commission. (2015a). Communication from the Commission to the European Parliament, the Council, the European Economic and Social Committee and the Committee of the Regions. The European agenda on security. COM (2015) 185 final, 28/4/2015.

European Commission. (2015b). Communication from the Commission to the European Parliament, the Council, the European Economic and Social Committee and the Committee of the Regions. A European Agenda on migration. COM (2015) 240 final, 13/5/2015.

European Commission. (2015c). Communication from the Commission to the European Parliament and the Council. Progress Report on the implementation of the hotspots in Greece. COM (2015) 678 final, $15 / 12 / 2015$.

European Commission. (2015d). Annexes to the communication from the Commission to the European Parliament and the Council. Progress report on the implementation of the hotspots in Italy. COM (2015) 679 final, 15/12/2015.

European Commission. (2016a). Annex to the communication from the Commission to the European Parliament and the Council on the state of play of implementation of the priority actions under the European agenda on migration. Italy: State of play report. COM (2016) 85 final, 10/2/2016.

European Commission. (2016b). Report from the Commission to the European Parliament, the European Council and the Council. Second report on relocation and resettlement. COM (2016) 222, 12/4/2016.

European Commission. (2016c). Report from the Commission to the European Parliament and the Council. Report on the progress made in the fight against trafficking in human beings (2016) as required under Article 20 of Directive 2011/36/EU on preventing and combating trafficking in human beings and protect- 
ing its victims. COM (2016) 267 final, 19/5/2016.

European Commission. (2016d). Report on the progress made in the fight against trafficking in human beings (2016) as required under Article 20 of Directive 2011/36/EU on preventing and combating trafficking in human beings and protecting its victims. SWD (2016), 19/5/2016 159 final.

European Commission. (2017). Press Release: Relocation and resettlement: Steady progress made but more efforts needed to meet targets. Retrieved from http://europa.eu/rapid/press-release_IP-17-908_en. htm

European Commission, DG Migration \& Home Affairs. (2015). A study on smuggling of migrants. Characteristics, responses and cooperation with third countries. Retrieved from http://ec.europa.eu/dgs/ home-affairs/what-we-do/networks/european_migr ation_network/reports/docs/emn-studies/study_on _smuggling_of_migrants_final_report_master_0911 15_final_pdf.pdf

European Migration Network. (2015). Inform on migrants' movements through the Mediterranean. Retrieved from https://ec.europa.eu/home-affairs/ sites/homeaffairs/files/what-we-do/networks/euro pean_migration_network/reports/docs/emn-inform s/emn_inform_movementsmediterranean_final.pdf

European Parliament, \& Council of the European Union. (2008). Directive 2008/115/EC of the European Parliament and of the Council of 16 December 2008 on common standards and procedures in Member States for returning illegally staying third-country nationals. OJ L 348/98, 24/12/2008.

European Parliament, \& Council of the European Union. (2011). Directive 2011/36/EU of the European Parliament and of the Council of 5 April 2011 on preventing and combating trafficking in human beings and protecting its victims, and replacing Council Framework Decision 2002/629/JHA. OJ L. 101/1, 15/4/2011.

European Parliament, \& Council of the European Union. (2013). Directive 2013/33/EU of the European Parliament and of the Council of 26 June 2013 laying down standards for the reception of applicants for international protection (recast). OJ L 180/96, 29/6/2013.

European Parliament, \& Council of the European Union. (2016a). Draft Regulation of the European Parliament and of the Council on a European travel document for the return of illegally third-country nationals (first reading). Doc 10638/16, 28 June 2016.

European Parliament, \& Council of the European Union. (2016b). Regulation (EU) 2016/1624 of the European Parliament and of the Council of 14 September 2016 on the European Border and Coast Guard and amending Regulation (EU) 2016/399 of the European Parliament and of the Council and repealing Regulation (EC) No 863/2007 of the European Parliament and of the Council, Council Regulation (EC) No 2007/2004 and Council Decision 2005/267/EC. OJ L 251/1, 16.09. 2016.
Europol. (2016). Migrants smuggling in the EU. Retrieved from https://www.europol.europa.eu/sites/ default/files/publications/migrant_smuggling_euro pol_report_2016.pdf

Fargues, P., \& Bonfanti, S. (2014). When the best option is a leaky boat: why migrants risk their lives crossing the Mediterranean and what Europe is doing about it. Retrieved from http://cadmus.eui.eu/handle/1814/ 33271

Fedotov, Y. (2016). Statement of UNODC Executive Director Yury Fedotov on Italian criminal investigation known as "Glauco 1". Retrieved from https://www. unodc.org/unodc/en/press/releases/2016/February/ statement-of-unodc-executive-director-yury-fedotov -on-italian-criminal-investigation-known-as-glauco-1. html

Frontex. (2016). Risk analysis for 2016. Retrieved from http://frontex.europa.eu/assets/Publications/Risk_ Analysis/Annula_Risk_Analysis_2016.pdf

G. and R. 2013 Case C-383/13 PPU, EU:C2013:533.

Group of Experts on Action against Trafficking in Human Beings. (2013). Report concerning the implementation of the Council of Europe Convention on Action against Trafficking in Human Beings by Spain. Retrieved from https://rm.coe.int/168063c3dc

Group of Experts on Action against Trafficking in Human Beings. (2014). Rules of procedure for evaluating implementation of the Council of Europe Convention on Action against Trafficking in Human Beings by the parties. THB-GRETA (2014)52, November 2014. Retrieved from https://rm.coe.int/16805a983c

Group of Experts on Action against Trafficking in $\mathrm{Hu}$ man Beings. (2015). 5th general report on GRETA's Activities covering period 1 October 2014 to 31 December 2015. Retrieved from https://rm.coe.int/ $168063093 \mathrm{c}$

Hirsi Jamaa and Others v. Italy 2012 Application no. 27765/09.

House of Lords European Union Committee. (2016). EU action plan against migrant smuggling. 4th Report of Session 2015-16. HL Paper 46.

Human Rights Watch. (2015). Counter illegal smuggling and trafficking while upholding migrants' and asylum seekers' rights. Retrieved from https://www. hrw.org/report/2015/11/16/europes-refugee-crisis/ agenda-action

Ineli-Ciger, M. (2015). The missing piece in the European agenda on migration: The Temporary Protection Directive. Retrieved from http://eulawanalysis.blog spot.co.uk/2015/07/the-missing-piece-in-europeanagenda-on.html

Ineli-Ciger, M. (2016). Time to activate the Temporary Protection Directive. European Journal of Migration and Law, 18(1), 1-33.

International Organisation for Migration. (2017). Migration flows-Europe. Retrieved from http://migration. iom.int/europe

Ippolito, F. (2016). La 'tragedia' delle frontiere Europee. 
European Papers, 1(2), 653-664.

Kamino International Logistics 2014 Case C-129/13 EU:C:2014:2041.

Khlaifia and others v. Italy 2015 Application no. 16483/12. L.E. v. Greece 2016 Application no. 71545/12.

Mogherini, F. (2015). Remarks by High Representative/ Vice-President Federica Mogherini following the informal meeting of the EU Foreign Ministers, Gymnich. Retrieved from http://eeas.europa.eu/ statements-eeas/2015/150905_01_en.htm

Mukarubega 2014 Case C-166/13 EU:C:2014:2336.

Peers, S. (2015). Temporary protection. In S. Peers, V. Moreno-Lax, M. Garlick, \& E. Guild (Eds.), EU immigration and asylum law (text and commentary): Volume 3: EU Asylum Law (pp. 571-598). Leiden: Hotei Publishing.

Pro Asyl. (2016). Vulnerable lives on hold. Refugees are hardly surviving the mass camps in the Athens region. Retrieved from https://www.proasyl.de/wpcontent/uploads/2015/12/2016-05-24-Vulnerable-li ves-on-Hold-final.pdf

Procura della Repubblica presso il Tribunale di Palermo 2014 [Arrest warrant issued by the Prosecutor's Office at the Court of Palermo, District Antimafia Directorate]. Decreto di Fermo disposto dal P.M.-art 384 c.p.p.

Rantsev v. Cyprus and Russia 2010 Application no. 25965/04.

Siliadin v. France 2015 Application no. 73316/01.

Statewatch. (2015). Explanatory note on the "hotspot" approach. Retrieved from http://www.statewatch. org/news/2015/jul/eu-com-hotsposts.pdf

Texdata Software 2013 C-418/11 EU:C:2013:588.

The Global Initiative Against Organised Crime. (2014). Smuggled futures: The dangerous path of the migrants from Africa to Europe. Retrieved from http:// globalinitiative.net/download/global-initiative/Glob al\%20Initiative\%20-\%20Migration\%20from\%20Africa a\%20to\%20Europe\%20-\%20May\%202014.pdf, p. 1, accessed on 30/11/2014

Triandafyllidou, A., \& Maroukis, T. (2012). Migrant smuggling: Irregular migration from Asia and Africa to Europe. Palgrave Macmillian.

United Nations High Commissioner for Refugees. (2007). Refugee protection and mixed migration: A 10-point plan of action. Retrieved from http://www.unhcr. org/4742a30b4.html

United Nations High Commissioner for Refugees. (2016). Refugees/Migrants emergency response: Mediterranean. Retrieved from http://data.unhcr.org/medi terranean/regional.php

Ventrella, M. (2007). Protecting victims of trafficking in human beings in the UK: The Italian Rimini method that could influence the British approach. Journal of Migration and Refugee Issues, 3, 64-86.

Ventrella, M. (2010). The control of people smuggling and trafficking in the EU: Experiences from the UK and Italy. Oxford: Routledge.

Webber, F. (2015). 'Hotspots' for asylum applications: Some things we urgently need to know. Retrieved from http://eulawanalysis.blogspot.co.uk/2015/09/ hotspots-for-asylum-applications-some.html

\section{About the Author}

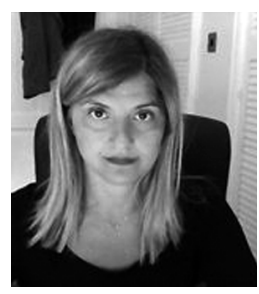

Matilde Ventrella is a senior lecturer in law at the Law School of the University of Wolverhampton where she organises courses in Asylum and Immigration law and teaches Constitutional and Administrative Law at undergraduate and postgraduate levels. Matilde Ventrella has a law degree from the University of Bari, an LLM from the University of Dundee, and a PhD from the University of Birmingham. Her research interests include human trafficking and its connections to people smuggling, as well as the protection of victims and potential victims of human trafficking by analysing international law and national law responses. 